University of California, Hastings College of the Law UC Hastings Scholarship Repository

Faculty Scholarship

2016

\title{
The CRISPR Revolution: What Editing Human DNA Reveals About the Patent Systems DNA
}

Robin Feldman

UC Hastings College of the Law, feldmanr@uchastings.edu

Follow this and additional works at: https://repository.uchastings.edu/faculty_scholarship

\section{Recommended Citation}

Robin Feldman, The CRISPR Revolution: What Editing Human DNA Reveals About the Patent System's DNA, 64 UCLA L. Rev. Disc. 392 (2016).

Available at: https://repository.uchastings.edu/faculty_scholarship/1552

This Article is brought to you for free and open access by UC Hastings Scholarship Repository. It has been accepted for inclusion in Faculty Scholarship by an authorized administrator of UC Hastings Scholarship Repository. For more information, please contact wangangela@uchastings.edu. 


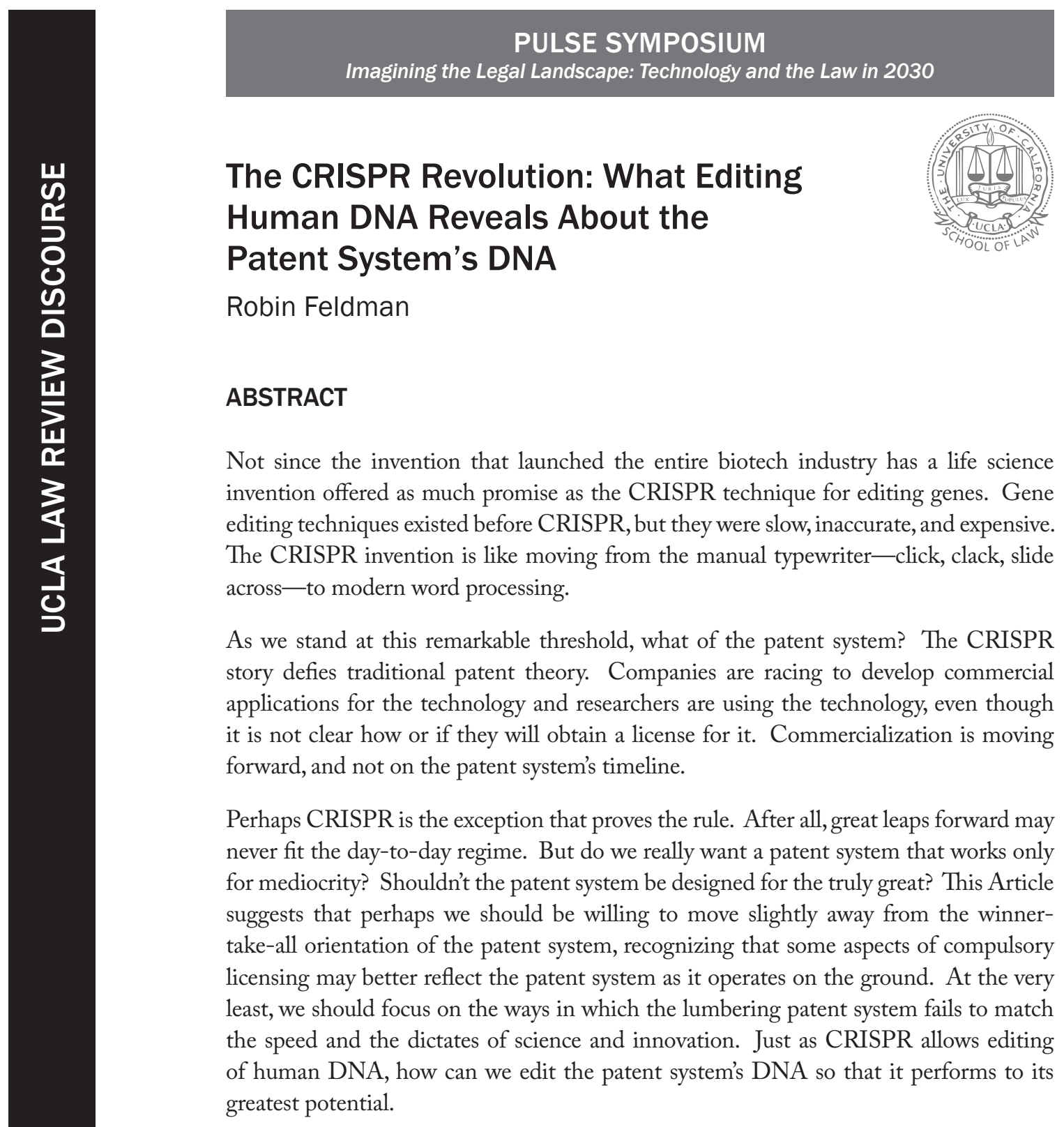

64 UCLA L. Rev. Disc. 392 (2016) 


\section{AUTHOR}

Harry \& Lillian Hastings Professor and Director of the Institute for Innovation Law, University of California Hastings College of the Law. The Institute's Startup Legal Garage program matches early stage companies with students and supervising attorneys at outside law firms for free legal work. Caribou, which was founded by the University of California's clustered regularly-interspaced short palindromic repeats (CRISPR) inventor group, was matched by the program in the company's early stages. The Institute receives no privileged or confidential information, but reading about the company spurred the author's interest in the science of CRISPR and its implications for the patent system. The author also notes the general affiliation of the University of California Hastings and the broader University of California system. I am grateful to Evan Frondorf and Connie Wang for invaluable research assistance and to Shelley Ackerman and Nathan Kipniss for comments on prior drafts. I also wish to thank participants in the UCLA Program on Understanding Law, Science, and Evidence (PULSE) Symposium on "Imagining the Legal Landscape: Technology and the Law in 2030" for their comments and reflections.

\section{TABLE OF CONTENTS}

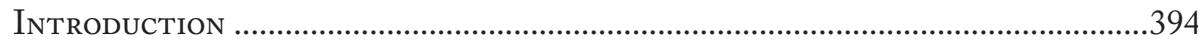

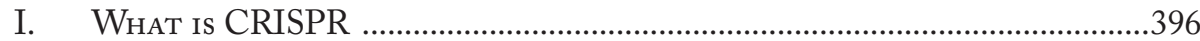

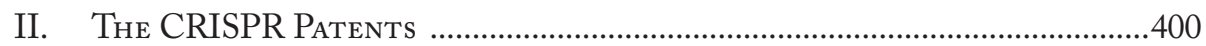

III. Implications of CRISPR for the Patent System ......................................404 


\section{INTRODUCTION}

Imagine that genes in all life forms, including plant, animal, and human, could be easily edited. Like the search and replace function of a word processor, errors in an individual's genetic code could be repaired or replaced, creating the ability to edit out devastating disease-causing errors, test medical treatments, and perform a variety of industrial tasks. The CRISPR revolution does not bring this futuristic vision fully into focus-but it comes close.

Not since the invention that launched the life science company Genentech and the entire biotech industry has a life science invention offered such promise. It is no exaggeration to say that if CRISPR lives up to that promise, the technology could well be one of the greatest life science inventions of all time. Gene editing techniques existed before CRISPR, but they were slow, inaccurate, and expensive. CRISPR technology can guide gene editing components to a particular spot so that genetic material can be cut or added, in a way that is vastly simpler than previous technologies. The invention is like moving from the manual typewriter-click, clack, slide across— to modern word processing. ${ }^{1}$

As we stand at this remarkable threshold, what of the patent system? Patents are supposed to be the engine of science and technological progress, providing the critical incentive that will encourage our citizens to invest in the creation of great innovations and to bring those innovations forth for the benefit of society. After all, the theoretical basis for the patent system rests on the narrative that the lure of patent rights will encourage invention that would not otherwise occur, or at least would occur later. ${ }^{2}$ Taking this narrative a step further, some scholars have argued that to ensure ideas are properly translated into commercial products, the patent system needs to have strong, early protection or additional protections. ${ }^{3}$ According to the argument, without

1. See Jennifer Kahn, The Crispr Quandry, N.Y. Times MAG. (Nov. 9, 2015), http://www.nytimes.com/2015/11/15/magazine/the-crispr-quandary.html

[http://perma.cc/WF43-JJTD] (noting that some researchers have compared clustered regularly-interspaced short palindromic repeats (CRISPR) to a word processor capable of editing down to a single letter).

2. See Mark A. Lemley \& Robin Feldman, Patent Licensing, Technology Transfer, E' Innovation, 106 Am. ECON. REV.: PAPERS \& PROC. 188, 188 (2016); see also William M. LANDES \& RICHARD A. POSNER, THE ECONOMIC STRUCTURE OF INTELlECTUAL PROPERTY LAW 294, 316 (2003); John F. Duffy, The Marginal Cost Controversy in Intellectual Property, 71 U. CHI. L. REV. 37, 41 (2004).

3. I have referred to these as "commercialization-plus" theories. See Lemley \& Feldman, supra note 2, at 11; see also Michael Abramowicz, The Danger of Underdeveloped Patent Prospects, 92 
such strong and early protection, no one will have the incentive to try to commercialize the invention.

The CRISPR story defies both of these narratives. Companies are racing to develop commercial applications for the technology and researchers are using the technology, even though it is not clear how or if they will obtain a license for it. The uncertainty exists because patents on the CRISPR technology are mired in a fight that will take years to emerge from the U.S. Patent \& Trademark Office (UPSTO), let alone work its way through any court proceedings. No one is willing to sit on the sidelines, however. Commercialization is moving forward, and not on the patent system's timeline.

Rather than serving as an essential vehicle for commercialization, patents appear to be largely peripheral to the CRISPR scientific applications underway. Companies are letting the patent system work through its slow, awkward dance on the theory that when the drama has played out, they will work out whatever licenses are necessary. Thus, in the case of CRISPR, the patent system is not fully playing the role that patent theorists might expect; it is a somewhat embarrassing and irritating sideshow. ${ }^{4}$

This is not to suggest that the patent system is playing no role at all in the CRISPR odyssey. As detailed below, two groups are fighting mightily to obtain the patent prizes. Commercialization, however, is moving forward despite this pitched battle. Rather than serving as the vehicle for bringing forth products for society, the patent system most likely will play a back-end role of dividing up the spoils.

CORNELL L. REV. 1065, 1067-71 (2007); Michael Abramowicz \& John F. Duffy, Intellectual Property for Market Experimentation, 83 N.Y.U. L. REV. 337, 395-408 (2008); Scott Kieff, Property Rights and Property Rules for Commercializing Inventions, 85 MINN. L. REV. 697, 707-12 (2001); Edmund W. Kitch, The Nature and Function of the Patent System, 20 J.L. \& ECON. 265, 275-80 (1977); F. Benjamin N. Roin, Unpatentable Drugs and the Standards of Patentability, 87 TEX. L. REV. 503, 557-58 (2009); Ted Sichelman, Commercializing Patents, 62 STAN. L. REV. 341, 345 (2010). Commercialization-plus theories have received their share of criticism. See RoBIN FELDMAN, RETHINKING PATENT LAW 76-78 (2012); Feldman \& Lemley, supra note 2, at 12; Mark A. Lemley, The Economics of Improvement in Intellectual Property Law, 75 TEX. L. REV. 989, 1046-52 (1997); Mark A. Lemley, Ex Ante Versus Ex Post Justifications for Intellectual Property, 71 U. CHI. L. REV. 129, 130 (2004); Mark A. Lemley, The Myth of the Sole Inventor, 110 MICH. L. REV. 709, 738-45 (2012); Robert P. Merges \& Richard R. Nelson, On the Complex Economics of Patent Scope, 90 COLUM. L. REV. 839, 843 (1990).

4. See, e.g., Stephen S. Hall, The Embarrassing, Destructive Fight Over Biotech's Big Breakthrough, SCI. AM. (Feb. 4, 2016), http://www.scientificamerican.com/article/the-embarrassingdestructive-fight-over-biotech-s-big-breakthrough [http://perma.cc/S42W-BKJX]; Sarah Zhang, Internet Outrage Is Shaping the Battle Over CRISPR, WIRED (Jan. 20, 2016, 1:00 PM), http://www.wired.com/2016/01/crispr-twitter-fight [http://perma.cc/A6CM-Y927]. 
Perhaps CRISPR is the exception that proves the rule. After all, great leaps forward may never fit the day-to-day regime. But do we really want a patent system that works only for mediocrity? Shouldn't the patent system be designed for the truly great? Regardless of whether CRISPR lives up to its promise, the experience should prompt us to examine the functioning of the patent system. Perhaps we should be willing to move slightly away from the winner-take-all orientation of the patent system, recognizing that some aspects of compulsory licensing may better reflect the patent system as it operates on the ground. At the very least, we should focus on the ways in which the lumbering patent system fails to match the speed and the dictates of science and innovation. Just as CRISPR allows editing of human DNA, how can we edit the patent system's DNA so that it performs to its greatest potential?

\section{WHATIS CRISPR?}

CRISPR genome editing technologies are derived from the bacterial version of an immune system, which consists of short bacterial DNA sequences and CRISPR associated (Cas) proteins. ${ }^{5}$ Together, these allow bacteria to recognize and destroy viruses. The acronym CRISPR stands for "clustered regularly-interspaced short palindromic repeats," and it is no wonder scientists developed a short form for that mouthful. The full name offers clues into how these sequences are structured within the bacterial genome. CRISPR consists of socalled "spacer" sequences that are incorporated from viruses or other foreign entities. $^{6}$ These spacer sequences are sandwiched in-between short, repeating sequences that read the same forward and backward. ${ }^{7}$ These sequences form the CRISPR array, which serves as a memory of past infections.

Although the following details about RNA may seem technical, they are important for understanding the leap that CRISPR innovators made in creating a single, effective tool for cutting and editing. One must start by understanding RNA. RNA exists in all cells, and its primary role is to act as a messenger with instructions from DNA for the creation of proteins. The

5. Andrew Pollack, $A$ Powerful New Way to Edit DNA, N.Y. TiMES (Mar. 3, 2014), http://www.nytimes.com/2014/03/04/health/a-powerful-new-way-to-edit-dna.html?_r=0 [https://perma.cc/7UZV-9Y45]

6. Id.

7. Heidi Ledford, CRISPR, the Disruptor, 522 NATURE 20, 23 (2015), http://www.nature.com/polopoly_fs/1.17673!/mena/main/topColumns/topLeftColumns/pd f/522020A.pdf [http://perma.cc/CM53-QDPD]; Michael Specter, The Gene Hackers, NEW YORKER (Nov. 16, 2015), http://www.newyorker.com/magazine/2015/11/16/the-genehackers [http://perma.cc/9Z89-84V6]. 
CRISPR arrays, which serve as memories of past infections as described above, are transcribed into RNAs, which are then processed into shorter RNAs termed CRISPR RNA (crRNA). This crRNA pairs with another short RNA (tracrRNA) to activate and guide an enzyme to a viral or other foreign DNA sequence that has been identified by the crRNA. At this point, the enzyme goes to work at cleaving and destroying the offending DNA.

The existence of CRISPR sequences in bacteria had long been known, dating back to its 1980 s discovery by Japanese researchers. ${ }^{8}$ In 2005, a microbiologist showed that the "spacer DNA" located between the repeated sequences is actually made up of DNA incorporated from invading viruses, and in 2007, microbiologists working for a Danish food company found that CRISPR DNA were used as part of an immune response for the bacteria in yogurt. ${ }^{9}$

These discoveries related to natural CRISPR processes were only the beginning. It became clear that CRISPR systems had extraordinary promise as a simple, revolutionary mechanism for gene editing-in all organisms, not just bacteria. Gene editing previously was a lengthy, inefficient process, using comparatively crude techniques such as breeding, turning off (or knocking out) the expression of genes using special proteins, and imprecise DNA cleaving. As one scientist told the New York Times Magazine, "In the past, it was a student's entire Ph.D. thesis to change one gene." ${ }^{10}$ By isolating the processes that bacteria use to attack viruses, CRISPR can modify multiple genes-in days.

As discussed above, CRISPR systems naturally require cRNA to pair with tracrRNA to activate the cutting enzyme. Scientists now have created a single RNA molecule that combines both RNA sequences (the combination is called "guide RNA"), which allows the system to work in a wide variety of organisms. These guide RNAs are then introduced into cells alongside a particularly effective cutting enzyme called Cas9. For this reason, the research tool and gene editing system is sometimes referred to as CRISPR-Cas9. ${ }^{11}$

The power of the system is simple: A scientist can create a guide RNA tailored to a specific gene or DNA sequence, pair it with Cas9, and easily remove segments of DNA and replace them with new segments.

8. See Specter, supra note 7.

9. Id.

10. See Kahn, supra note 1.

11. See, e.g., Steph Yin, What Is CRISPR/Cas9 and Why Is It Suddenly Everywhere?, MOTHERBOARD (Apr. 30, 2015), http://motherboard.vice.com/read/what-is-crisprcas9and-why-is-it-suddenly-everywhere [http://perma.cc/5CG3-NNGD]. 
Theoretically, even single base pairs—single building blocks of genes—can be excised and replaced. It is, as many have described it, equal to a word processor for life, capable of changing biology as we know it. ${ }^{12}$

As discussed in Part II, infra, the timeline for CRISPR's development as a gene editing tool is complicated and disputed. ${ }^{13}$ There is general agreement, however, that Jennifer Doudna, a professor at the University of California, Berkeley, working with French researcher Emmanuelle Charpentier were the first to demonstrate that CRISPR could edit purified DNA, publishing their findings in Science in the summer of 2012. ${ }^{14}$ In early 2013, Feng Zhang, a faculty member at the Broad Institute of MIT and Harvard, published research demonstrating the use of CRISPR to modify human genes. ${ }^{15}$ Similar findings followed weeks later from other scientists, including from Doudna's lab. ${ }^{16}$

12. See, e.g., Farai Chideya, The Battle Over CRISPR Could Make or Break Some Biotech Companies, FivETHIRTYEIGHT (Jan. 25, 2016), http://fivethirtyeight.com/features/thebattle-over-crispr-could-make-or-break-some-biotech-companies; Kahn, supra note 1; Andrew Pollack, Jennifer Doudna, a Pioneer Who Helped Simplify Genome Editing, N.Y. TIMES (May 11, 2015), http://www.nytimes.com/2015/05/12/science/jennifer-doudnacrispr-cas9-genetic-engineering.html [http://perma.cc/KB4F-UGCP]; Specter, supra note 7.

13. For example, see the controversy over a CRISPR history published in Cell by Eric Lander, a scientist affiliated with the Broad Institute. See generally Eric S. Lander, The Heroes of CRISPR, 164 CELL 18 (2016). Commentators, including Doudna and Charpentier, have criticized the article for historic inaccuracies and potential conflicts of interest. See Jennifer Doudna, Comment to The Heroes of CRISPR, PuBMED COMMONS (Jan. 17, 2016, 10:31 PM), http://www.ncbi.nlm.nih.gov/pubmed/26771483\#cm26771483_13783 [http://perma.cc/3R GU-QREE]; Emmanuelle Charpentier, Comment to The Heroes of CRISPR, PUBMED COMMONS (Jan. 19, 2016, 5:09 PM), http://www.ncbi.nlm.nih.gov/pubmed/26771483\#c m26771483_13792 [http://prma.cc/\#RGU-QREE]; see also Sharon Begley, Controversial CRISPR History Sets Off an Online Firestorm, STAT (Jan. 19, 2016), http://www.stat news.com/2016/01/19/crispr-history-firestorm [http://perma.cc/TN5X-UHXY]; Tracy Vence, "Heroes of CRISPR" Disputed, SCIENTIST (Jan. 19, 2016), http://www.the-scientist.com/ ?articles.view/articleNo/45119/title/-Heroes-of-CRISPR—Disputed [http://perma.cc/U4XJ9N5K].

14. Martin Jinek et al., A Programmable Dual-RNA-Guided DNA Endonuclease in Adaptive Bacterial Immunity, 337 SCI. 816 (2012), http://www.sciencemag.org/content/337/6096/ 816.full [https://perma.cc/E4QA-LRN9].

15. Le Cong et al., Multiplex Genome Engineering Using CRISPR/Cas Systems, 339 SCI. 819 (2013), http://www.sciencemag.org/content/339/6121/819?ijkey=e17a392b4636e5f5c926d 502eb4348f7b83114c4\&keytype2=tf_ipsecsha [http://perma.cc/v8U8-7SEJ]; see Specter, supra note 7.

16. Martin Jinek et al., RNA-Programmed Genome Editing in Human Cells, ELIFE (Jan. 29, 2013), http://elifesciences.org/content/2/e00471v1 [http://perma.cc/HSM9-8K59]; Prashant Mali et al., RNA-Guided Human Genome Engineering via Cas9, 339 SCI. 823 (2013), http://www.sciencemag.org/content/339/6121/823?ijkey=e251986cc54e88189dc5a 9be5949fffa8c8ca522\&keytype2=tf_ipsecsha [https://perma.cc/82JB-4CL4]. 
The technique has quickly spread throughout biological research. The implications of CRISPR technology are numerous and profound, ranging from improved yogurt flavor to long-awaited disease cures. ${ }^{17}$ For example, Chinese scientists have already produced a wheat strain resistant to powdery mildew, a persistent pest, simply by deleting genes. ${ }^{18}$ Unsurprisingly, however, the promise of direct human applications is receiving the most attention. One straightforward use is the removal or repair of disease-causing genes by modifying body cells. ${ }^{19}$ In mice, researchers already have fixed the genetic mutations that cause sickle-cell anemia, muscular dystrophy, and cystic fibrosis. ${ }^{20}$ In addition, Zheng's company has announced plans for clinical trials for a cell therapy technique that uses CRISPR to cure a rare form of blindness. ${ }^{21}$

As many commentators have noted, however, CRISPR's true power may lie not in cell repair but in drug development based on CRISPRpowered research into the underlying causes behind disease. Previous techniques for drug development, much like older gene editing models, could not be specifically targeted. They relied on "association studies" that used aggregate samples of disease carriers to determine if sufferers have mutations in common, a technique that frequently pointed to hundreds of possible genes. ${ }^{22}$ Now, CRISPR allows for the simple modification of tens or hundreds of genes at a time, making it far easier to test all possible options and find better avenues for new drug development. Progress in cancer-fighting drugs is particularly likely to be boosted. Cancer cells often need to be targeted by multiple drugs, and their susceptibility may vary from patient to patient. CRISPR will permit more rapid, systematic testing and modeling of how cancers develop and can be defeated. Recent research also demonstrates CRISPR's potential for improving organ transplantation. By removing viruses common in pig DNA, organs from pigs may become viable candidates for transplant into humans. ${ }^{23}$

CRISPR, however, is not immune to controversy. The technology theoretically could be used to modify germline cells in human embryos, making fully inheritable alterations to genomes. Traits then could be propagated from

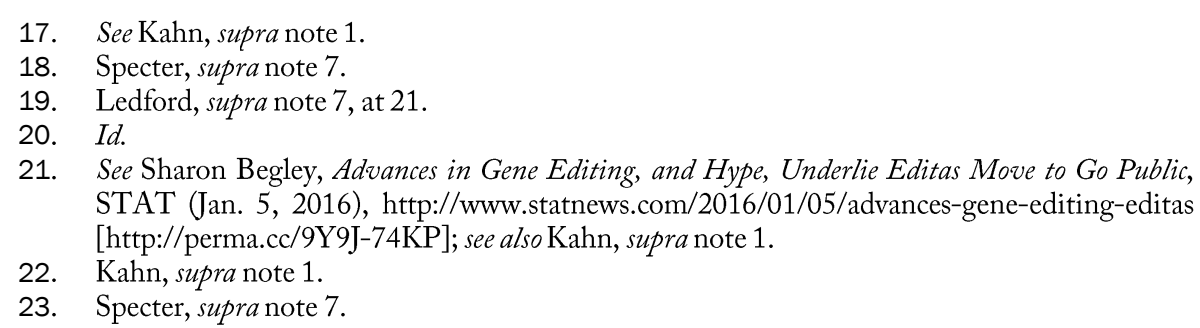


generation to generation such that genetically-inherited diseases might be completely eliminated. Although there is excitement about genetically-engineered cures, others worry about eugenics and "designer babies" created to maximize intelligence and attractiveness. ${ }^{24}$ In particular, a group of Chinese scientists sparked fears in the spring of 2015, when they announced they had attempted to repair a gene for a blood disorder in nonviable embryos. ${ }^{25}$ The U.S. Congress banned research on embryo editing in its 2016 budget, ${ }^{26}$ and a group of scientists, led by Doudna, called for a moratorium on germline cell editing. ${ }^{27}$ At a December 2015 international conference in Washington, D.C., experts agreed that there should be a ban on clinical use on germline editing until a "broad societal consensus" is reached. ${ }^{28}$ In short, CRISPR continues to send shock waves throughout the scientific world, from the extraordinary opportunities for research and disease treatment to industrial applications to ethical considerations. And just as CRISPR is creating waves in the scientific seas, it is also creating waves in the patent realm.

\section{THECRISPRPATENTS}

Despite controversy over potential use of CRISPR in embryonic cells, the less contentious applications of the technology are numerous and immediate for science, medicine, and industry. As one scientist told the New York Times Magazine, "You've got Fortune 50 companies fighting with start-ups fighting with universities. That almost never happens. But with [CRISPR],

24. See, e.g., Ledford, supra note 7, at 20-21; Amy Maxmen, Easy DNA Editing Will Remake the World. Buckle Up., WIRED (July 22, 2015), http://www.wired.com/2015/07/crispr-dnaediting-2 [http://perma.cc/WB4R-BDNA]; Pollack, supra note 12; Specter, supra note 7.

25. David Cyranoski \& Sara Reardon, Embryo Editing Sparks Epic Debate, 520 NATURE 593, 593 (2015), http://www.nature.com/news/embryo-editing-sparks-epic-debate-1.17421\#/b1 [http://perma.cc/DF9V-6WKE]; Puping Liang et al., CRISPR/Cas9-Mediated Gene Editing in Human Tripronuclear Zygotes, 6 PROTEIN \& CELL 363, 363 (2015); see also Specter, supra note 7 , at 53-56 (discussing varying reactions to the embryo research).

26. Jeffrey Mervis, Updated: Budget Agreement Boosts U.S. Science, SCI. (Dec. 18, 2015, 12:30 PM), http://www.sciencemag.org/news/2015/12/updated-budget-agreement-boosts-usscience [http://perma.cc/N6BT-2UGQ].

27. David Baltimore et al., A Prudent Path Forward for Genomic Engineering and Germline Gene Modification, 348 SCI. 36 (2015), http://www.sciencemag.org/content/348/6230/36 [http://perma.cc/CC2X-9KTZ]; see also Ledford, supra note 7; Nicholas Wade, Scientists Seek Ban on Method of Editing the Human Genome, N.Y. TIMES (Mar. 19, 2015) http://www.nytimes.com/2015/03/20/science/biologists-call-for-halt-to-gene-editingtechnique-in-humans.html?_r=0 [http://perma.cc/JWH3-ACAM].

28. Press Release, Organizing Committee for the International Summit on Human Gene Editing, National Academies of Sciences, On Human Gene Editing: International Summit Statement (Dec. 3, 2015), http://www8.nationalacademies.org/onpinews/newsitem.aspx? RecordID=12032015a [http://perma.cc/YN9A-KUM8]. 
the range of potential uses is so huge-everybody wants in." ${ }^{29}$ Thus, the stakes for intellectual property ownership are extremely high, with hundreds of millions of dollars of funding already raised by CRISPR companies. ${ }^{30}$ These include companies founded by research leaders in the field, such as Doudna's Caribou Biosciences, ${ }^{31}$ Charpentier's CRISPR Therapeutics, ${ }^{32}$ and Zhang's Editas Medicine. ${ }^{33}$

These and other CRISPR users must license the technology from those who hold patent rights, but the question of who holds what patent rights is tied up at the United States Patent and Trademark Office (USPTO). ${ }^{34}$ The parties in dispute are Doudna (alongside Charpentier) and Zhang. ${ }^{35}$ In March of 2013, Doudna filed a patent application with 155 claims to the general CRISPR-Cas9 technology. ${ }^{36}$ Seven months later in October of 2013, Zhang filed a patent application for his findings. ${ }^{37}$ Given that Zhang's patent had no more than three independent claims and twenty total claims directed toward a single invention, it was eligible for a special accelerated examination track, and his patent issued on April 15, 2014..$^{38}$

29. Kahn, supra note 1.

30. See Paul B.G. van Erp et al., The History and Market Impact on CRISPR RNA-Guided Nucleases, 12 VIROLOGY 85, 88 (2015), http://www.sciencedirect.com/science/article/pii/ S1879625715000425 [http://perma.cc/8PKJ-WMKV]; Chideya, supra note 12, at paras 6-7; Maxmen, supra note 24, at paras 36-38.

31. CARIBOU BIOSCIENCES, http://cariboubio.com [http://perma.cc/4NYA-2U92].

32. CRISPR THERAPEUTICS, http://crisprtx.com [https://perma.cc/6YDA-MS6Q].

33. EDITAS MEDICINE, http://www.editasmedicine.com [https://perma.cc/755Z-JS2N].

34. See generally Jacob S. Sherkow, The CRISPR Patent Interference Showdown Is on: How Did We Get Here and What Comes Next?, STAN. L. SCH.: L. \& BIOSCIENCES BLOG (Dec. 29, 2015), https://law.stanford.edu/2015/12/29/the-crispr-patent-interference-showdown-is-on-howdid-we-get-here-and-what-comes-next [https://perma.cc/4AEU-7C6M] (outlining history of the CRISPR patent dispute and complex "interference proceedings" between Doudna and Zhang).

35. Note that under the U.S. Supreme Court's ruling in Myriad, CRISPR in its naturallyoccurring form is not patentable. The patentable elements are the methods of using CRISPR for gene editing and other therapeutic applications. Ass'n for Molecular Pathology v. Myriad Genetics, Inc., 133 S. Ct. 2107, 2111 (2013) (finding that naturally occurring DNA sequences cannot be patented); see also Kristin Beale, The CRISPR Patent Battle: Who Will Be "Cut" out of Patent Rights to One of the Greatest Scientific Discoveries of Our Generation?, BOS. C. INTELL. PROP. \& TECH. F. 88, 91-92 (Winter 2015-16).

36. U.S. Patent Application No. 13/842,859 (filed Mar. 15, 2013) (priority date May 25, 2012), http://www.google.com/patents/US20140068797. Doudna's application has a priority date of May 2012, when the initial provisional application was filed. See id.

37. U.S. Patent No. 8,697,359 (filed Oct. 15, 2013) (issued Apr. 15, 2014), http://www.google. $\mathrm{com} /$ patents/US8697359. Zhang's application had a priority date of December 12, 2012, also seven months after Doudna's priority date. See id.

38. See Sherkow, supra note 34. See generally Petition to Make Special Under Accelerated Examination Program, United States Patent and Trademark Office, Docket No. 44790.05.2003 (Oct. 15, 2015), http://www.scribd.com/doc/294235157/414-Make-Special 
Doudna's team then filed an interference proceeding, in which a patent applicant argues that an already issued patent or pending patent application "interferes" with the applicant's ability to obtain its patent. ${ }^{39}$ Interferences are relics of the patent regime prior to passage of the America Invents Act, in which the United States moved from a first-to-invent system to a first-to-file system. Interferences are designed to determine who was the first to invent. ${ }^{40}$ The USPTO granted Doudna's request for an interference proceeding on January 11, 2016, and the proceedings are underway with a variety of disputed claims pulled into the process. ${ }^{41}$ The patent proceedings are likely to take years to resolve, including potential court appeals. ${ }^{42}$ In the meantime, as the patent system lumbers on, innovation moves forward unabated.

This is not the first time a major life science invention has marched to a different beat. In the early 1970s, researchers from Stanford University and the University of California developed a genetic tool that would later give birth to the biotech industry. Stanley Cohen, Herbert Boyer, and Paul Berg used a purified enzyme to allow individual genes to be copied, moved, and studied. ${ }^{43}$ The universities applied an unusual licensing strategy for what would become known as the Cohen-Boyer patents. Recognizing the

[https://perma.cc/23QQ-GUMM]. The application must also have twenty or fewer total claims. Zhang's application had exactly three independent claims and twenty total claims. See supra note 34.

39. Suggestion of Interference Pursuant to 37 C.F.R. § 41.202, In re Patent Application of Jennifer Doudna et al., U.S. Patent Application Serial No. 13/842,859 (Apr. 13, 2015), http://www.scribd.com/doc/294235581/Interference [https://perma.cc/6BMP-WCEE].

40. See Leahy-Smith America Invents Act, Pub. L. No. 112-29, 125 Stat. 284 (2011) (codified as amended in scattered sections of 35 U.S.C.); Mark Summerfield, CRISPR-Will This Be the Last Great US Patent Interference?, PATENTOLOGY (July 11, 2015, 8:08 PM), http://blog.patentology.com.au/2015/07/crispr-will-this-be-last-great-us.html [https://perma.cc/4J72-XNEA].

41. Declaration of Interference, Broad Inst. v. Regents of the Univ. of Cal., No. 106,048 (P.T.A.B. Jan. 11, 2016); Heidi Ledford, Bitter Fight Over CRISPR Patent Heats Up, 529 NATURE 265 (Jan. 12, 2016), http://www.nature.com/news/bitter-fight-over-crispr-patentheats-up-1.17961 [https://perma.cc/PX6F-Y93W].

42. Heidi Ledford, How the US CRISPR Patent Probe Will Play Out, 531 NATURE 149, 149 (Mar. 10, 2016), http://www.nature.com/news/how-the-us-crispr-patent-probe-will-playout-1.19519 [https://perma.cc/WU7K-M9LZ]; Sharon Begley, Clash of Scientific Titans: CRISPR Hits the Courts, With Money and Prestige at Stake, STAT: IN THE LAB (Mar. 8, 2016), https://www.statnews.com/2016/03/08/crispr-patent-fight/ [https://perma.cc/3T7ZWSBD].

43. Jeremy M. Grushcow, Measuring Secrecy: A Cost of the Patent System Revealed, 33 J. LEG. STUD. 59, 62 n.3 (2004). 
revolutionary and far-reaching nature of the invention, licenses were given to large numbers of users at a relatively low price. ${ }^{44}$

The licensing approach encouraged the widespread use of the technology, launching an entire industry while creating a handsome return for university coffers. The universities earned $\$ 200$ million from the patents, ${ }^{45}$ along with extraordinary good will. Some commentators have asserted that companies were willing to take licenses even if the strength of the patents or the need for the license was unclear. ${ }^{46}$ As one expert noted "the Cohen-Boyer patents had become the '[B]ambi' of the university community; nobody wanted to shoot [B]ambi." ${ }^{\prime 4}$

The Cohen-Boyer licensing program defied both conventional wisdom and patent theory. Conventional wisdom held, and in many corners continues to hold, that exclusive licensing is essential for commercialization of patents. The general notion is that no company will invest in developing or commercializing the patented technology unless that company is guaranteed to have an exclusive license. ${ }^{48}$ Following this logic, the Bayh-Dole Act of 1980, which gave universities the right to patent federally funded inventions, grew in part out of a concern that these inventions would never be commercialized unless a single party had the right to control commercialization and could grant exclusive licenses. ${ }^{49}$ That exclusive only theory has not held up across time. The Cohen-Boyer program of widespread, nonexclusive licensing suggests the opposite, and evidence indicates that most modern university licenses are nonexclusive. ${ }^{50}$

44. See Peter Mikhail, Hopkins v. CellPro: An Illustration That Patenting and Exclusive Licensing of Fundamental Science Is Not Always in the Public Interest, 13 HARV. J.L. \& TECH. 375, 382$83(2000)$

45. Grushcow, supra note 43 , at 62 n.3.

46. See Mikhail, supra note 44, at 382-83.

47. See id. at 383 (quoting Harold Wegner).

48. See Lemley \& Feldman, supra note 2; $c f$. Ian Ayres \& Lisa Larrimore Ouellette, A Market Test for Bayh-Dole Patents, 102 CORNELL L. REV. (forthcoming 2016) (suggesting a market test for university patents, requiring them to offer a free nonexclusive license, and allowing them to grant an exclusive license only if no one takes them up on that offer).

49. See Council on Governmental Relations, The BayH-Dole Act: A Guide to THE LAW AND IMPLEMENTING REGULATIONS (1999); Lemley \& Feldman, supra note 2.

50. See David C. Mowery et al., The Effects of the Bayh-Dole Act on U.S. University Research and Technology Transfer, in INDUSTRIALIZING KNOWLEDGE: UNIVERSITY-INDUSTRY LiNKAGES IN JAPAN AND THE UNITED STATES 269, 283, 294, 297 (Lewis M. Branscomb et al. eds., 1999) (noting that Columbia, University of California, and Stanford have licensed many inventions nonexclusively and that their most profitable licenses are nonexclusive); Jerry G. Thursby \& Marie C. Thursby, University Licensing, 23 OxF. REV. ECON. POLICY 620, 626-27 (2007) (citing Association of University Technology Managers data from 2004 indicating that 54.5 percent of university licenses are nonexclusive). 
In addition, the Cohen-Boyer patent licenses were crafted in a form that has received considerable criticism in other contexts. Those who took a license paid a small fee up front with a promise of royalties from any eventual products manufactured with discoveries made by using the technology. ${ }^{51}$ In modern terms, this could be characterized as a form of "reach-through royalty." Reach-through royalties are now strongly discouraged by the National Institutes of Health because of their potential to overburden products with too many layers of payments. ${ }^{53}$ In addition, some, including this author, have asserted that reach-through royalties constitute misuse of a patent. ${ }^{54}$ Nevertheless, the Cohen-Boyer licensing program was extremely effective and had a legendary impact on science and innovation. As with the CRISPR story, Silicon Valley understood its own needs better than any patent theorists.

\section{IMPLICATIONS OF CRISPR FORTHEPATENT SYSTEM}

One could argue that the CRISPR patent saga is merely an echo of a patent system prior to the changes in the America Invents Act, and that the effects of the prior system will fade across time. CRISPR, indeed, may be one of the last interference proceedings ever seen. ${ }^{55}$ Even with the America Invents Act's new system, however, no one would suggest that the patent system is a speedy and efficient endeavor in which clear, reliable outcomes are the norm. ${ }^{56}$ Complaints frequently sound from the computer technology realm,

51. See Kenneth Sutherlin Dueker, Biobusiness on Campus: Commercialization of UniversityDeveloped Biomedical Technologies, 52 FOOD \&DRUG L.J. 453, 495 (1997).

52. See Rebecca S. Eisenberg, Technology Transfer and the Genome Project: Problems With Patenting Research Tools, 5 RISK: HEALTH, SAFETY \& ENV’T 163, 172 (1994) (same but noting that reach-through royalties on the Harvard onco-mouse have met greater market resistance); Patrick Hagan, Note, Reach Through Royalties as a Workaround for Patent Exhaustion, 2 HASTINGS SCI. \& TECH. L.J. 243, 244 (2010) (characterizing the Cohen-Boyer licenses as a form of reach-through royalties, similar but distinguishable).

53. See Principles and Guidelines for Recipients of NIH Research Grants and Contracts on Obtaining and Disseminating Biomedical Research Resources: Final Notice, 64 Fed. Reg. 246 (Dec. 23, 1999).

54. See Robin C. Feldman, The Insufficiency of Antitrust Analysis for Patent Misuse, 55 HaSTINGS L.J. 399, 439-49 (2003).

55. See, e.g., Summerfield, supra note 40.

56. See, e.g., U.S. GOV’T ACCOUNTABILITY OFFICE, INTELLECTUAL PROPERTY: ASSESSING FACTORS THAT AFFECT PATENT INFRINGEMENT Litigation COUlD HelP IMPROVE PATENT QUALITY (2013) (concluding that modern problems related to patent lawsuits filed by nonpracticing entities are largely attributable to patent quality); see also FELDMAN, supra note 3 (arguing that a patent grant provides the opportunity to bargain over the definition of rights, rather than creating a definitive boundary of rights). And a number of empirical studies have documented the frequency with which lower court patent claim constructions are overturned by the Federal Circuit. Christian A. Chu, Empirical Analysis of 
in which innovation happens rapidly and inventions may be obsolete by the time the patents issue. ${ }^{57}$ There, patents run the risk of interfering with innovation, rather than fostering it. Nevertheless, the CRISPR experience shows that the life science industry is not immune to fast leaps forward and to innovations out of sync with the operation of the patent system and its theoretical underpinnings.

As described above, the patent system is intended to provide incentives for people to invest in creating and bringing forth innovations for the benefit of society. Patents are supposed to be a game of winner-takes-all, in which the one who arrives first (whether it is the first-to-file or the first-to-invent) wins. In this vein, the structure of the patent system stands in contrast to that of other intellectual property regimes in which society recognizes rights of multiple parties to the chase. Thus, the patent system does not have extensive prior user rights, as found in trademark law. ${ }^{58}$ Nor does the patent system have independent creation defenses, as found in copyright law. ${ }^{59}$ In short, the patent system does not focus on partial rights for those who came close, but lost by a nose. The winner, and only the winner, is supposed to take all.

This design follows a fundamental theoretical vision deeply entwined in the patent system. The utilitarian vision of the patent system reflects the belief that assigning rights to inventions will ensure that brilliant ideas are translated into

the Federal Circuit's Claim Construction Trends, 16 BERKELEY TECH. L.J. 1075, 1104 (2001); Kimberly A. Moore, Are District Court Judges Equipped to Resolve Patent Cases?, 15 HARV. J.L. \& TECH. 1, 8-10 (2001); Andrew T. Zidel, Patent Claim Construction in the Trial Courts: A Study Showing the Need for Clear Guidance From the Federal Circuit, 33 SETON HALL L. REV. 711, 738-40 (2003).

57. See, e.g., Julie E. Cohen \& Mark A. Lemley, Patent Scope and Innovation in the Software Industry, 89 CALIF. L. REV. 1, 5 (2001) (arguing that patent law must be refined to accommodate the rapid sequential innovation that takes place in the software industry); Mark Lemley, Software Patents and the Return of Functional Claiming, 2013 WIS. L. REV. 905, 930 (2013) (noting that computer technology changes so rapidly that software patents are often asserted against technologies far removed from the original patented invention); Peter S. Menell, Tailoring Legal Protection for Computer Software, 39 STAN. L. REV. 1329, 1350-51 (1987) (noting that the mismatch between the speed of evolution in computer technologies and the long delays associated with patenting significantly reduce the benefits of seeking patent protection for computer programs); Wendy Seltzer, Software Patents and/or Software Development, 78 BROOK. L. REV. 929, 968 (2011) (arguing that using patents to create incentives in the software industry may stifle innovation).

58. Keith A. Barritt, Prior User vs. Federal Registrant: Whose Mark Is It, Anyway?, FISH \& RICHARDSON (Feb. 18, 2009) http://www.fr.com/news/prior-user-vs-federal-registrantwhose-mark-is-it-anyway1/ [https://perma.cc/E57Y-UULY].

59. Gideon Parchomovsky \& Alex Stein, Intellectual Property Defenses, 113 ColuM. L. REV. 1483, 1493 (2013). 
products for the benefit of society. ${ }^{60}$ The patent system has no interest in knowledge for its own sake, which is derided in the historic patent literature as a "mere curiosity." ${ }^{11}$ Rather, the patent system focuses on incentivizing applied industrial products—what is known in the economic literature as "innovation" and somewhat similar to the notion of "translational" work in the life sciences. ${ }^{62} \mathrm{In}$ short, a winner-takes-all system is supposed to optimize the creation of viable commercial products for everyone to enjoy. ${ }^{63}$

The winner-takes-all construct fits particularly well within a theoretical framework that has been receiving considerable attention in the patent world in recent years. According to this theoretical perspective, the patent system needs to have early or additional protections to incentivize the investment necessary to ensure commercialization. Originating with Edmund Kitch's famous "prospect theory" expounded in the 1970s, this call for earlier and enhanced protections is echoing in a variety of scholarship today-all focused on the concern that commercialization of ideas will not occur without such protections. ${ }^{64}$

A theoretical framework in which a winner takes all and that winner is crowned early in the process looks quite different from a framework that contemplates partial victories or sharing the spoils. Nevertheless, the patent system increasingly appears to allow such shared victories. Rather than incentivizing the creation and development of innovation up front, the patent system frequently plays the role of dividing up the spoils at the end of the day. This is true not only for spectacular inventions such as CRISPR, which politely ignore the patent licensing system, but for many run of the mill patent cases.

60. See supra note 2; see also Robin Feldman, Intellectual Property Wrongs, 18 STAN. J.L. BuS. \& FIN. 250, 252 (2013) (explaining that from the store of commercial activities that might otherwise be open to all, we remove some for a limited period of time and dedicate them to the few to optimize commercial innovation for all of us).

61. 1 William C. ROBINSON, THE LAW OF PATENTS FOR USEFUL INVENTIONS 463, ch. IV, $\S 339$ (1890) (foundational treatise section expounding on the notion of patents and industrial use).

62. See Lemley \& Feldman, supra note 2 (explaining that the patent system's focus is consistent with economic literature which distinguishes invention—an idea—from innovation—turning the idea into a viable product).

63. For an in-depth discussion of these theoretical notions, see $i d$; see also Lemley \& Feldman, supranote 2.

64. Kitch, supra note 3, at 265, 275-80. See generally Abramowicz, supra note 3 (proposing a system of patent extension auctions to counteract the problem of patent underdevelopment); Abramowicz \& Duffy, supra note 3 (arguing that the intellectual property regime should be modified to encourage market experimentation, rather than just technological experimentation); Kieff, supra note 3 (suggesting that treatment of patents as property rights is necessary to incentivize commercialization); Sichelman, supra note 3, at 345 (proposing a new "commercialization" patent alongside traditional invention patents to encourage greater rates of commercialization). 
For example, the patent litigation system looks more like bargaining than winner-takes-all. Roughly three-quarters of all patent lawsuits never proceed to trial because they are either settled by the parties or dropped. ${ }^{65}$ For the small percentage of patent lawsuits that proceed to trial and a judgment of infringement, many of those dollar awards are reduced by appellate judges or by posttrial settlement between the parties. ${ }^{66}$ The same pattern holds true for patent demand letters, with estimates suggesting that more than 90 percent of patent demands never proceed to the courthouse steps because they are either dropped or settled. ${ }^{67}$ Lawsuits and demands that settle clearly represent a bargaining result. In addition, one could argue that dropping a patent lawsuit or demand also represents a form of settlement from the perspective that one side of the potential bargain has given up and walked away.

Such a post-hoc process, in which people bargain to divide up the spoils, looks quite different from the notion of creating an incentive to invest through the promise of a winner-takes-all reward. And if the patent system's original conceptualization of behavior and incentives does not fully match what is happening on the ground, what is driving inventors, and what role is being played by patents?

It is certainly plausible that the promise of back-end rewards, no matter how remote, incentivizes the front-end innovation. I have yet to see the empirical evidence suggesting we can measure this with confidence, although it seems likely to be happening. The argument may have less force with university inventions, given that other rewards—such as advancement of one's academic career-contribute to the drive to create and may muddy attempts to measure the incentive effects of the patent reward.

Nor do the parties seem to be operating according to pristine patent theory. At least for CRISPR, no one is waiting to see who will be the "winner of all." They are simply moving forward anticipating that bargaining eventually will sort everything out.

Many other startups formed from university research operate in an analogous manner, moving first and sorting out the licensing later. University contracts and policies may provide that the university owns whatever a faculty member "conceives of" or "reduces to practice" during the time that the faculty member is employed by

65. See generally Robin Feldman et al., The ALA 500 Expanded: The Effects of Patent Monetization Entities, 17 UCLAJ.L. \& TECH. 1,59-60 (2013) (empirical analysis of all 13,000 lawsuits over fouryears).

66. See, e.g., Lucent Techs. Inc. v. Gateway, Inc., 509 F. Supp. 2 d 912 (S.D. Cal. 2007) (vacating a jury award of $\$ 1.53$ billion in damages for insufficient evidence to establish the correct royalty base), affd, 543 F.3d 710 (Fed. Cir. 2008); see also Andrew Amerson, Gatekeeping Trends in Reasonable Royalty Cases, TEX. InTELLECTUAL PROP. L.J. (forthcoming 2017) (manuscript at 1, 8) (on file with author).

67. See Amerson, supra note 66 (manuscript at 32). 
the university. ${ }^{68}$ Thus, if professors want to start companies with inventions from their labs, they must get licenses from the university technology transfer office to do so. Many, however, move forward without resolving the licensing first. The licensing process is too slow, the company might never become viable, and it all can be sorted out in the end. Once again, the patent system's image - in which a single winner obtains full rights and coordinates licensing to commercialize the invention-does not correlate with what is happening on the ground.

If the life sciences, in their most spectacular moments like CRISPR, are operating outside the predicted norms of the patent system, what does this tell us? How do we adapt so that the patent system better fits the greatness we would like to bring forward? Or is greatness beside the point? In fact, one could argue that the modern patent system seems best-suited to mediocrity, given that patents often cover small, incremental advances. Is this a necessary design element of a patent system, or simply a flaw in its current configuration and application?

We could, and most likely will, continue tinkering with the diseases that plague the patent system. We can improve the post-grant review system, ${ }^{69}$ hire more examiners ${ }^{70}$ require a higher level of innovation to receive a patent, ${ }^{71}$ and adjust venue, ${ }^{72}$ pleading, ${ }^{73}$ and damages calculations ${ }^{74}$ in the hopes of ensuring more

68. See, e.g., Rutgers: The State University OF NEW JERSEY, RutGers Policy § 50.3.1, § 50.3.1(B) (2013), http://policies.rutgers.edu/sites/policies/files/50.3.1\%20-\%20current.pdf [https://perma.cc/9C74-WKSM]

69. See, e.g., Leahy-Smith America Invents Act, Pub. L. No. 112-29, 125 Stat. 284 (2011) (codified as amended in scattered sections of 35 U.S.C.).

70. See, e.g., Dennis Crouch, USPTO's Swelling Examiner Rolls, PATENTLY-O (Nov. 30, 2014), http://patentlyo.com/patent/2014/11/usptos-swelling-examiner.html [https://perma.cc/8AGANKUN].

71. See Jason Rantanen, The Federal Circuit's New Obviousness Jurisprudence: An Empirical Study, PATENTLY-O (Jan. 31, 2013), http://patentlyo.com/patent/2013/01/the-federal-circuitsnew-obviousness-jurisprudence-an-empirical-study.html [https://perma.cc/87L9-FM37] (demonstrating that the Federal Circuit has made it more difficult for patent holders to survive an obviousness challenge since the Supreme Court's 2007 decision in KSR v. Teleflex).

72. See, e.g., Dennis Crouch, Venue and Personal Jurisdiction Updates, PATENTLY-O (Mar. 19, 2016), http://patentlyo.com/patent/2016/03/personal-jurisdiction-updates.html [https://perma.cc/3PXC$\mathrm{P} 2 \mathrm{~F} 3]$ (noting the introduction of a new venuebill in the Senate).

73. See, e.g., Alexander Chen \& Omid Shabani, The Demise of Rule 84 and the Unleashing of Twombly, LAW360 (July 8, 2016, 11:55 AM ET), http://www.law360.com/articles/804020/ the-demis-of-rule-84-and-the-unleashing-of-twombly [https://perma.cc/4XBZ-M6R8] (describing impact of elimination of Form 18 for patent infringement pleadings after changes to the Federal Rules of Civil Procedure on December 1, 2015); Leeron Morad \& Andrew J. Bramhall, An Early Review of the Impact of Form 18's Elimination on Pleading Direct Infringement, PATENTLY-O (Apr. 6, 2016), http://patentlyo.com/patent/2016/04/elimination-pleading-infringement.html (describing impact of elimination of Form 18 for patent infringement pleadings after changes to the Federal Rules of Civil Procedure on December 1, 2015).

74. See Ryan Davis, Justices Take on \$400M Award in Apple-Samsung Patent War, LAW360 (Mar. 21, 2016, 9:43 AM ET), http://www.law360.com/articles/767858/justices-take-on-400m- 
uniform and better outcomes. At the very least, we should consider these and other changes that might coax the lumbering patent system to better reflect the speed and temperament of science and innovation. The topic of this symposium, however, invites far-reaching and ambitious musings on imagining the contours of a future legal landscape. In this spirit, one could try to use the CRISPR experience as an opportunity to consider germ line changes to the patent system. In particular, these could include some form of compulsory licensing, one that might better reflect the post-hoc bargaining that currently takes place.

There are a variety of potential advantages of having an overt compulsory licensing system, rather than a cloaked bargaining system that flies under the radar. For example, companies would no longer be pressed into operating outside a lumbering patent system that cannot keep pace with their innovations. In addition, bringing the bargaining into the light would reduce the incentive to engage in patent holdup or to drop eye-popping demands on the table that must be stripped away over time, with high transactions costs for parties and the courts. ${ }^{75}$ It might also coax the U.S. Supreme Court into allowing patent protection for a wider array of inventions, such as the medical diagnostic inventions that have been shut out of the system with recent decisions. ${ }^{76}$ In an all-or-nothing system, the Court may be tempted to opt for nothing, rather than cutting off future innovators for twenty years. ${ }^{77}$ Finally, when a system focuses on dividing up the spoils at the end of the battle, the little guy tends to lose. Some form of rationalized compulsory licensing might leave more room for small players and the disruptive innovation they can produce.

I have argued in the past that given the lack of a shared conception for things that are new, the limitations of language, and problems related to fixation in time, a patent can never definitively identify the metes and bounds of the rights. Rather, under any set of rules we could derive, a patent will always provide an opportunity to bargain — a seat at the negotiating table with certain rules in place. ${ }^{78}$ Some form of compulsory license system, one that

award-in-apple-samsung-patent-war [https://perma.cc/SH59-Q6GT] (noting that the Supreme Court granted certiorari in the famous Apple v. Samsung design patent case regarding the damages test for design patents).

75. See Amerson, supra note 66.

76. See Mayo Collaborative Servs. v. Prometheus Labs., Inc., 132 S. Ct. 1289, 1293-94 (2012) (rejecting patentable subject matter for a medical diagnostics patent).

77. See Lisa Larrimore Ouellette, Patentable Subject Matter \& Nonpatent Innovation Incentives, 5 U.C. IRvinE L. REV. 1115, 1117 (2015) (noting that the Supreme Court's cautiousness may stem from the starkness of the choice offered).

78. See FELDMAN, supra note 3, at 34, 211-12. 
better reflects innovation realities, would also be consistent with this theoretical analysis.

Germ line changes are the most dangerous for any organic system because they risk unintended consequences. After all, the U.S. innovation system is a key driver of the economy, and making fundamental changes to anything related to that system could be a perilous endeavor. Nevertheless, CRISPR provides a startling view of a patent system that is out of step. When technological innovation is moving despite the patent system, not because of it, perhaps it is time to take a closer look. 